\title{
The Principle of Dominance and the Limitation of Changing the Use of Agricultural and Garden Lands
}

\section{El principio de dominación y la limitación de cambiar el uso de las tierras agrícolas y de jardín}

\author{
Ali Akbar Nazari \\ PhD Student, Department of Jurisprudence and Fundamentals of Islamic Law, Mashhad Branch, \\ Islamic Azad University, Mashhad, Iran \\ ORCID: https://orcid.org/0000-0003-0648-9743

\section{Hossein Ahmari} \\ Associate Professor, Department Islamic Jurisprudence and Islamic Law, Mashhad Branch, \\ Islamic Azad University, Mashhad, Iran \\ ORCID: https://orcid.org/0000-0002-6037-6187

\section{Seyed Ahmad Ali Hashemi} \\ Assistant Professor, Department of Private Law, Mashhad Branch, Islamic Azad University, \\ Mashhad, Iran \\ ORCID: https://orcid.org/0000-0003-3052-9768
}

Received 02-08-20 Revised 04-10-20

*Correspondence

Email: ahmari.hosein@yahoo.com
Accepted 01-11-21 On line 01-12-21

Cite as:

Nazari, A., Ahmari, H., \& Hashemi, S. (2021). The Principle of Dominance and the Limitation of Changing the Use of Agricultural and Garden Lands. Propósitos $y$

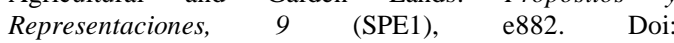
http://dx.doi.org/10.20511/pyr2021.v9nSPE1.882

(C) Universidad San Ignacio de Loyola, Vicerrectorado de Investigación, 2020. 


\section{Summary}

The purpose of the present study was to investigate the principle of dominance and limitations imposed on changing the use of agricultural and garden lands. The former and latter are considered as important subjects continuously debated and discussed. Changing the use of garden and agricultural lands is a theoretically argued subject and is followed by the principal question of: how in the face of the dominance principle, the legal limitations in changing the use of agricultural and garden lands are justifiable? In terms of the method of study.the present research falls into the category of descriptive-analytic researches, and library studies have been conducted to answer the mentioned question. The results of the present study indicate that illegal change of use of agricultural lands is an obvious instance of conflict between personal and societal rights. Because the owner of an agricultural land, due to his/her personal rights is allowed to use the land in any legitimate and legal way he/she desires; however, the rights of the society and the future humans forbids the owner to use the land in ways that would harm the public/society. Based on the stated content, it is concluded that the ownership right is absolutely preserved for the real owner based on the principle of dominance, but in cases where this right is conflictual with societal rights, the societal rights would be counted prioritized over the former, and therefore it would be necessary to control personal rights. This preference has a clear and obvious instance in the context of changing the use of agricultural and garden lands; and it is rational that the society's right will be dominant over the rights of the owner of agricultural and garden lands.

Keywords: change of use, retention of use, rights, dominance principle, principle of harm, agricultural lands.

\section{Resumen}

El propósito del presente estudio fue investigar el principio de dominancia y las limitaciones impuestas al cambio de uso de tierras agrícolas y de jardín. El primero y el segundo se consideran temas importantes de debate y discusión continua. Cambiar el uso de las tierras agrícolas y de jardín es un tema discutido teóricamente y es seguido por la pregunta principal de: ¿cómo, frente al principio de dominación, las limitaciones legales para cambiar el uso de las tierras agrícolas y de jardín son justificables? En cuanto al método de estudio. la presente investigación se enmarca en la categoría de investigaciones descriptivo-analíticas, y se han realizado estudios bibliotecarios para dar respuesta a la pregunta mencionada. Los resultados del presente estudio indican que el cambio ilegal de uso de tierras agrícolas es un ejemplo obvio de conflicto entre los derechos personales y sociales. Porque el propietario de una tierra agrícola, debido a sus derechos personales, puede usar la tierra en cualquier forma legítima y legal que desee; sin embargo, los derechos de la sociedad y de los futuros humanos prohíben al propietario utilizar la tierra de manera que perjudique al público / sociedad. Con base en el contenido expresado, se concluye que el derecho de propiedad está absolutamente preservado para el propietario real basado en el principio de dominio, pero en los casos en que este derecho esté en conflicto con los derechos de la sociedad, los derechos de la sociedad se considerarían priorizados sobre los primero, y por lo tanto sería necesario controlar los derechos personales. Esta preferencia tiene una instancia clara y obvia en el contexto de cambio de uso de tierras agrícolas y de jardín; y es racional que el derecho de la sociedad prevalezca sobre los derechos del propietario de tierras agrícolas y de jardín.

Palabras clave: cambio de uso, retención de uso, derechos, principio de dominio, principio de daño, tierras agrícolas 


\section{Introduction}

One of the most important and yet, applicable debates in the field of jurisprudence is the subject of dominance principle and its effects on ownership right. The mentioned principle which implies dominance over ownership, plays an important role in fortifying the rights of individuals. The principle of dominance is also known as the principle of domination; however, among jurists it is known as the principle of dominance. This principle maintains that any owner has full dominance over his/her owned property, and is free to dominate the property in any materialistic or non-materialistic manner. No one can prevent an owner from dominating his/her land without a legal permit. In the other words, by this principle and with respect to the existing jurisprudential verdicts, it is basically accepted that all types and kinds of domination are legit for owners, unless the contrary holds according to a legal and legitimate reason. The prophetic hadith of "الناس مسلطون عل امو الهم" is the basis for the dominance principle. This principle is one of the most popular jurisprudential principles and due to its extensive economic and social applications, is considered as one of the most basic jurisprudential principles. This principle maintains that every owner, has full dominance over their properties/belongings. In other words, this principle fortifies the pillars of ownership and based on it, the owner is allowed to dominate his/her property in any way, whether materialistically or incorporeally; allowing no one to ban the owner from legitimately dominating the property without legal permit. In the other words, according to this principle, it is accepted that the owner is allowed to dominate the property in any way, unless legitimately inappropriate. Due to the special place of properties and belongings in people's everyday lives, this principle is bolder compared to other subjects. Both in divine schools, and in non-divine systems, the importance of properties and ownership is considered as a basic undoubted principle for regulation of social and economic relations between the members of a society, in a way that there is even a prophetic hadith for it, maintaining that a Muslim's property is to be respected just as the Muslim him/herself (Ibn Abd Rabe, 1940, v2, p357). The dominance principle maintains that first of all, it is the owner's right to dominate his/her property; and secondly, it is a haram act for the others to enter or dominate a property without the owner's consent. In this sense, in 1996 and with the goal of retention of use of garden and agricultural lands as well as keeping the profitability and efficiency of such lands the legislator of Iran passed the law of "retention of use of garden and agricultural lands", in order to prevent the changing of such lands' use. According to the law, changing the use of agricultural and garden lands is forbidden, unless in exceptional/emergency cases. The violators will be forced to pay taxes in addition to paying a fine of up to 3 times the price of the land with the new use. The main question that rises here is that how the limits of changing the use of agriculture and garden lands are set in the face of the dominance principle? In the other words, when based on the dominance principle the owner is allowed to dominate his/her property in any desired way, how the limitations in changing the use of agricultural and garden lands are justifiable? The present article tries to answer this question.

\section{Dominance Principle}

The mentioned content made it clear that all humans can dominate their properties in any desired way. The question that rises here is whether this dominance is absolute or it is bound to specific terms and limitations? By referring to verses and narratives it becomes clear that property dominance is not absolute, rather divine sources have considered limits and terms for it, which must be adhered to. For instance, in terms of belonging, the property is conditioned to be free from corruption. For example, a body, blood, pig meat and carnivore meat and or any other polluted (unclean/najis) substance will not be included in the ownership dominance permit. In addition, in terms of manner of acquisition, ownership has certain limitations, maintaining that it must be formed through trading and be based on the consent of the both sides. On this basis, although based on the dominance principle, the owner will have full dominance over a property, but the dominance of the owner is bound to certain limitations and terms. What is comprehended from narratives and news is that the principle of dominance applies to human properties, leaving the question whether this principle covers the rights and 
individuals or not? In terms of dominance over rights, Makarem Shirazi maintains that other than what the owner has mentioned in the contract regarding the individuals' dominance over their rights, I have not seen or heard of any other similar narratives. However, the owner rationalizes based on reason and priorities, meaning that when people dominate their properties, they will also have dominance over the rights as well (Makarem Shirazi, 1991, v2, p26).

However, in terms of dominance over individuals, Makarem Shirazi refers to jurisprudential principles and states: dominance over individuals in neither found in texts nor in the narratives quoted from scholars. If by dominance over an individual it is meant the type of dominance generated by leasing/renting, then the dominance is undoubtedly allowed. Because, first of all, although human acts are not verbally equal to properties, but they are potentially equal to properties; and also if even this is not accepted, the logical basis accepts it anyways. In addition, dominance is formally recognized for marriage and similar examples. But if by dominance of the self, it is meant that the person is allowed to commit suicide, the dominance would not be accepted, and would be prohibited.

In addition, based on the hadith of " لا يحلّ لامرئ مال اخيه الّا عن طيب نفسا" (Abu Davood Sajestani, $\mathrm{Bi}$ Ta, v2, p1905), dominating other's properties is forbidden, unless under the consent of the owner. The significant importance of the principle of dominance which fortifies the notion of ownership, has significantly influenced newer law schools without exceptions; in a way that the majority of the regulations codified to regulate economic affairs and setting the boundaries for economic relationships between the society members in newer legislation systems, are in fact essentially based on the principle of dominance and its related derivatives. The omnipresence of this principle in different jurisprudential texts and documents, signifies its strong position. In addition, the principle of dominance acknowledges reason, showing that it is a rational, intellect based law. In vocabulary, dominance or dominating means to have privilege and superiority over another (Johari Ibn Manzour, Morteza Zubeida); and in terms of law, it denotes the owner's right to dominate his/her property in any desired way (Mostafavi, 1997, p136). Some jurists and lawyers also refer to it as the principles of authority and reign (Najafi, 2017, v24, p478; Makarem Shirazi, 1993, v2, p17; Mostafavi, Previous).

The principle of dominance fortifies the components of ownership, and with respect to the importance of issues of properties and ownership, the entire newer law schools have accepted this principle, while Iran's civil code's articles 30 and 31 also point to this principle (Mohaqeq Damad, 2003, v2, p94). Therefore, if we want to scrutinize this principle on its own, we must say that that all individuals are allowed to dominate their properties in any desired way. One important topic regarding the principle of dominance is how to clear its conflict with the noharm principle in cases where even legitimate and legal dominance of the owner over his/her property causes harms to others and the society as well. Many jurists prefer to prioritize the dominance principle, and consider such dominations legitimate (Sheikh Toosi, 1973, v3, pp272273). However, some other jurists refer to the no-harm principle and believe such dominations are illegitimate (Ibn Qodame, 1987, v5, p52; Sistani, 1993, p328; Shirazi, 1997, v5, p266). On the other hand, some other lawyers/jurists believe that the principle of no-harm would only be preferred over the dominance principle if there is a great deal of damage (Mohaqeq Sabzevari, 1269 A.H, p241). Here, in order to elaborate on the legitimate and legal prohibition of unauthorized domination of owners in their agricultural lands, once the principle of dominance is scrutinized, it would be necessary to explain the relationship between the principles of dominance and no-harm.

\section{Methodology}

\section{The Relationship between the Dominance and No-Harm Principles}

The present research is descriptive-analytical, so in this research, the library method has been used.

Another popular jurisprudential principle considered for in majority of jurisprudential cases is 
the principle of no-harm. In summary the principle of no-harm maintains that in Islam, causing harm to others does not have any legitimacy in neither of the phases of legislation and enforcement.

It is obvious that even in cases where the owners' actions/dominations cause harm and damage to others, there is no conflict between the principles of no-harm and dominance, and it is simple a case of accumulation. Because it is not a requirement of benefiting from a land to harm others, however in some cases it would be infeasible to execute both of the principles at the same time, and the explanation would be that there exists an essential difference between accumulation and contradiction. Contradiction takes place in the phase of legislation whereas, accumulation takes place in the execution phase. This is why we have phrases like accumulation of verdicts and, contradiction of reasons. The relationship between the principles of no-harm and dominance is of this type. So if the domination of the owner in his/her property does not cause any harms to others, there would be no contradiction or accumulation, however, some dominations may be harmful and cause damages to others. In this case, the principles of no-harm and dominance form an accumulation case, and one must seek ways to perfectly flatten the situation of friction between the two principles according to intellectual and legal criteria (Tavakoli, 2003, p42).

The ownership right is the most perfect objective right, and by perfect it is meant that this right grants its owner the entire authorities to use and exploit. It creates real ownership, by which the owner can dominate his/her property in any desired way, but with respect to explicit legal exceptions. For example, the owner would be authorized to waste his/her property, or abandon it, or even completely or partially transfer it to another individual, or bail it for someone else's demands.

According to the principle of dominance, the owner is allowed to dominate his/her property in any desired way, without anyone being able to bother him/her. Conflict between this principle and the principle of no-harm is natural, because the latter has been put in place to control and limit the ownership rights born by the dominance principle in the first place. Now, ways must be sought to solve the problem in case of occurrence of a conflict between the two principles. Different jurists hold different views regarding this subject; however, in order to create a better understanding, these cases are divided into two main and large categories:

a) Cases in which the owner's dominance over his/her property does not cause harms to others, but impedes their benefaction. In these cases, the principle of dominance will be preferred, and according to it, the owner's domination/dominance is legitimate.

b) Cases in which the owner's dominance over his/her property does cause harms to others. Here there would be three different assumptions:

1- If the owner does not dominate his/her property and it results in his/her loss, the principle of dominance will be preferred.

2- If the owner does not dominate his/her property, and resultantly he/she does not get benefitted, based on the view of some jurists the principle of dominance is preferred, however, some other jurists believe that the no-harm principle must be preferred.

3- If the owner does not dominate his/her property and by not doing so neither he/she gets harmed, nor his/her benefit is mitigated, then the principle of no-harm will be preferred.

Undoubtedly the scope of the dominance principle is limited and the owner cannot refer to this principle to justify all types of dominance; rather even based on this principle, the domination of the owner in the property must comply with regulations, rules and laws, in a way that even in the absence of the no-harm principle, the owner would still not be allowed to dominate in ways that would cause harm and damage to others. In the other words, domination of the owner over the property must be logical, and if the owner executes any sort of non-logical domination over his/her property, the domination will be null. 


\section{The Place of the Principles of No-Harm and Dominance in Law}

One important issue dealt with today, concerns the debate of dominance principle in jurisprudence and its effects on the ownership right in Iranian law. Islam has several infrastructural principles each of which is a certain important source for legislation. The principle of interest which implies dominance over properties, plays an important role in Iranian law. The significant importance of the principle of dominance which fortifies ownership, has exercised immediate effects on the newer law schools, in a way that the majority of laws laid to regulate the economic affairs as well as to set limits for economic relationships between the members of society, are in fact essentially based on this principle and its derivatives as well. In this regard, the article 22 of the constitution of Iran states that fame, life, properties and close relatives of individuals are immune to offense, unless subjected to a legal subpoena.

Regarding the conflict between the no-harm and dominance principles, the civil code also prefers the no-harm principle over the other. In the civil code, in cases of conflict with the noharm principle legislators have subjected individuals' dominance right to certain limitations. In fact, the verdicts anticipated by the articles 592, 591, 159, 139, 138, 132, 122, 114, 65, 833, 600, 594, and 1130 of the civil code entail that in certain cases it is emphasized on the individuals' right to dominate/dominance right, in a way that it is warned that this right may be misused by ill will. On this basis, it can be stated that the legislators of the Iranian civil code have not been explicit enough in dealing with conflicts between the principles of dominance and no-harm. Resultantly, while the element of ill will has been considered as a reason for depriving rightowners from enforcing their full dominance rights, it has not been recognized in Iranian civil code (Qahremani, 2006, p126). It seems that in order to fill this legal gap, the courts can refer to the article 40 of the constitution which forbids the misuse of rights. Referring to this principle, will, in many cases deprive the right-owner from misusing their legal advantages.

The Article 40: no one is allowed to use their privilege to enforce their rights as a tool to harm others or violate public benefits.

Enforcement of the ownership right in Iran is subjected to certain conditions stated by the article 132 of the civil code. According to this article, if the act of enforcing the ownership right harms another individual, it must only be enforced to the extent that it shields the owner of the right from harm, so that no liability is born for the enforcer.

\section{The Conflict between Personal and Social Rights}

In this section, we will deal with the question whether the owner has unlimited dominance over his/her property or not? If it is limited, what are the bound? Undoubtedly, the Prophet Muhammad has considered limitations for the dominance of individuals over their properties, on this basis religious texts agree that whenever a harm is inflicted on others through an owner's dominance over his/her property, if the harmed party is undoubtedly damaged in the view of law, the owner will be held responsible (Hor Ameli, Bi Ta, pp179-181; Ravayat Bab 8\&9, from the liability bearing venues). On this basis, no jurist can be found who believes in absolute dominance of an owner over his/her property and rejects any sort of limitation even if the dominance results in harming or loss of benefits. If the infliction of loss and deprivation from benefits is absolutely required for dominance, then the act of dominating will not be responsibility bearing. On the other hand, it can be stated that the holy prophet does not hold any strict views about the authorities of owners, because if he did, he would have had stated it clearly. On this basis, it is clear that the subject under debate is rational, and so it has been said: since the principle of human's dominance over its properties is a rational principle, therefore not all types of domination, especially those that inflict harms on others while not relieving the owner from harms or giving him/her benefits, 
are considered as righteous (Makarem, 1991, p39). In addition, we cannot consider absolute dominance for owners' demands either, whereas as some jurists maintain that in the light of the principle of dominance, all owners are authorized to demand their properties anywhere they desire (Ansari, 1997, p39).

What is debatable at this point, is the question whether the owners' rights are absolute and unconditional or it is bound to certain limitations under specific conditions? In the other words, in case of conflict between the owner's right and others' rights, will the owner's right and his/her dominance over the property be preferred over the others' social right or not?

Undoubtedly, in every society the members have rights that need to be considered for when envisaging laws; in the other words, the public rights must never be shadowed by the rights of certain members of that society, and if the contexts required for suppression of rights and injustice are prepared, the Islamic Ruler is obliged to prevent infliction of harm on the society. On this basis, it can be stated that one condition applied to the dominance law is that enforcing the ownership right over the property must not result in harming and inflicting damages on others, and if this was the case, the dominance of the owner over the property will be altered and bound to certain limitations. This itself, is a case of exception from generality of the dominance of the owner, which has pointed top in the civil code as well, and also the constitution of the Islamic republic of Iran explicitly states this (Mahmoodi Golpaigani, 2006, p237).

One instance of violation of public rights due to enforcement of the principle of dominance, is the dominance of ownership rights on the owned agricultural lands. It is obvious that the committer of the offence of unauthorized change of use of agricultural lands will unconsciously result in devastation of agricultural lands and their exclusion from the process of domestic production, while endangering food security, self-efficiency and sustainability of employment in societies, especially rural ones.

In such cases, there would be a conflict between the personal rights and individuals' ownership dominance, and public rights. Undoubtedly, under such circumstances where the right to dominate and enforce the dominance right will result in infliction of harm on the public, social rights will be prioritized over the personal rights, meaning that the owner's right to dominate must be limited. According to jurists, such instances denote conflicts between the principles of dominance and no-harm, where eventually the principle of no-harm will be preferred and prioritized over the dominance principle, because the philosophy behind the former is to limit the dominance of owners in cases where it inflicts damages on others (Sobhani, Bi Ta, p126).

On this basis, changing the use of agricultural lands will surely result in irreparable damages to the nature, bearing negative consequences such as expansion of deserts, erosion of the soil, occurrence of natural disasters such as landslide, flood and climate change, as well as destruction of the vegetation, reduction of life variability, infertility of lands, and also other negative environmental consequences including contamination of water sources by unauthorized polluting industries, especially alongside the riverbanks, coasts and areas adjacent to reservoirs of drinking and agriculture waters, and eventually gradual death of agriculture, which imposes serious threats on food security. In the views of social science experts, in addition to the mentioned environmental consequences, the change in land use tackles structural changes in social, economic, and physical dimensions of villages, which has caused inequality of income between the villagers and spread of discrimination and injustice, emergence of domestic conflicts and cultural contradictions, loss of family identity, increased tendency for migration, depletion of enthusiasm for making long-term agricultural plans, reduced generative employment, and ultimately, irreparable social and cultural defects in lives of villagers. It is natural that under such conditions, the solution to the problem is out of the hands of the public; rather it is the governing system that must take decisive action to overcome the problems of the society based on jurisprudence. 


\section{The Relationship between the Principle of Dominance and the Offense of Agricultural Lands use Change}

Now that the principles of no-harm and dominance have been scrutinized, we will elaborate on the relationship between retention of land use of agricultural lands and these two principles in order to understand the philosophy behind the sentence of retention of land use of agricultural lands. It must be taken into account that the ownership right and the owner's right to dominate his/her property is normally accepted in an absolute manner if it creates no conflict with others' rights. Whenever there is friction between this right and the public rights, since it is more necessary and preferred to preserve the rights of the public, then the ownership right cannot be enforced in an absolute manner. In other words, under the rule and priority of the principle of preserving the public rights and the necessity to keep it out of harm's way, as already established the owner's right to dominate the property will be subjected to certain limitations.

In all cases of conflict between the ownership right and dominance over the properties, and the principle of no-harm, the preferred principle will be the no-harm principle, requiring limitations set for the ownership right. Therefore, referring to the principle of dominance in the case of changing the land use of agricultural and garden lands would be nonsense. The criteria of such preference or prioritization has clear instances regarding the offense of changing the land use of agricultural and garden lands. It is natural that the public rights will be prioritized over the landowner's rights. On this basis, legal authorities will usually issue a verdict to destruct the structures built upon agricultural and garden lands, while holding the offender responsible and considering a cash fine of up to three times the value of the land after changing its use.

On this basis, the rights of the owners and their dominance over their properties will be respected as long as they don't interfere with others' rights, because ownership is a permanent right allowing the individual to dominate a property in a desired way and benefit from it, but within the limits set by the law. However, in cases where it enters a conflict with public rights, the public rights will be prioritized. In addition, according to the principle of dominance, the Muslims are allowed to enforce any kind of domination over their properties, however, the principle is only referable when there is no conflict or friction with state regulations. The offense of changing the use of agricultural and garden lands is an obvious instance of violation of public rights which is followed by several irreparable and devastating effects. So the government must not ignore this; rather here the public rights are pre-eminent over the personal rights which must be limited.

\section{Prohibition of Misuse of Rights in Iran's Civil Code}

First of all, it must be said that article 132 of the civil code is a legal document for principle of prohibition of misuse of rights. Misusing rights means inflicting damage and harm on others through enforcing your rights (Nosrati Sedqiani, 2011, p9). This definition is exclusively concerning the misuse of ownership right, especially for neighboring lands. However, in terms of the civil code, it can be generalized to cover other issues as well.

In this section, we will take a look at the liability stated by the article 132 of the civil code, and will stress out its similarities with the articles 352-354 of the Islamic Punishment Law. The reason we will do so, is to know the limits of enforcement of the law, and to make it clear whether the mentioned law overlaps with the article 132 of the civil code or not.

The article 132 of the civil code states: no one can dominate his/her property in a way that it harms the neighbor, unless the dominance takes place in a way that only the owner is safeguarded against being harmed. By this article, legitimate and justifiable domination of property is authorized, even if it harms others.

On the other hand, articles 352-354 of the Islamic Punishment Law (IPL) are envisaged in a 
way that an ambiguity is created whether the subject of these articles is similar to that of the article 32 of the civil code or not. Since the articles 352-354 of the IPL have been envisaged prior to the article 132 of the civil code (CC), then these articles are specific to the article 132 of the CC. Here it is necessary to investigate the case under the light of analysis of the liability stated in the article 132 of the $\mathrm{CC}$ and the conditions of enforcement of right based on this article. Afterwards, the differences between this article and the articles 352-352 of the IPL can be stressed out. In the later topic, the possibility of matching the article 132 of the CC and the articles 352-354 of the IPL will be checked.

\section{Analysis of the Liability Stated in the Article 132 of the Civil Code}

Assume that a person has a right and wants it enforced, while another person will be harmed if the first person's right is enforced. If the owner of the right does not take action, he/she will be harmed and if he/she does, another one will be harmed. These two cases of harming will eliminate each other, only if their come to an agreement. For example, the life-loss and financial losses cannot eliminate each other, since they are incomparable. Obviously, clearing a life loss is more prioritized compared to an economic loss. What preference lies between the two right owners that allows the enforcer of the right to enforce it even if it will harm another one?

The social and materialistic world we live in is bound to certain limits that must coped with. One certain feature of social life is that many harms that would be caused by others must be considered legitimate. If enforcement of rights was supposed to be stopped only because of harming others, while not enforcing it would harm the right owner him/herself, then the extent of enforcement of rights would be too narrowed, which is considered as a threat to the social life and freedom of people. In the other words, someone who thinks their freedom has been violated, will think of a place to enforce their right where no one else lives. Because, by enforcement of many of the rights, there may be harms inflicted on other right owners. On this basis, even in case of inflicting harms on others, a certain advantage must be given to right owners.

On the other hand, if all people were allowed to enforce their rights freely and without considering others' rights, again the social life will be endangered, because by freely enforcing their rights, people will deprive others of their rights. What can be done now? The solution proposed for this situation maintains that enforcing the rights that would harm others is only legitimate as long as it is done to marginally save the right owner from being harmed. This is the solution proposed by the article 132 of the CC. in fact, based on this article, when there is a conflict between the rights of a person and others, both the harms imaginable for the right owner and the harms imaginable for the other parties will be taken into the account. Although this article relates to the issue of misuse of rights, especially the ownership rights, since the dominance of the owner results in the harming of the other and not dominating results in the harming of the owner, the issue of accumulation of the no-harm and dominance principles will be objected. the issue at hand, is the issue of misuse of rights, because the owner has used his/her right to dominate the land in an improper way that has caused harms to others. It is said that the person has misused his/her right of ownership. Here we have accumulation of the principles of no-harm and dominance. Referring to the dominance principle will cause in harming others when the no-harm principle has set limits to the former principle, and prohibits the infliction of harms on either of the sides. Dominating other's properties whether directly or indirectly, is outside the coverage of the principle of dominance and bears responsibility, unless under cases of emergency. Yet another point that must be stated regarding this article is that it would have had been better if the article 132 had used more general terms instead of stating the issue specifically, so that it would have had covered all types of dominance, and not only the ones related to properties and land. For example, instead of the word "property" the word "right" could be used while also the words "dominance" and "Neighbor" could be substituted by words "enforcement of right" and "others" respectively. 
The similarity between the definition of fault proposed by Jessraun and the article 132 of the CC is not in vain. Jessraun suggests to define fault as: harming others while the offender cannot prove that if he/she hadn't done so, a similar harm could have had occurred to himself/herself (Katoozian, 2010, p207). A principal point to be mentioned prior to explaining this article is that if the dominance of the owner in the property does not bear damages to others, it would be considered legitimate if it exceeded the threshold of safeguarding of the owner from harms at the time (Imami, 2005, v1, p55). The ownership right is limited to prevent harms. But when by such dominance, no damage or harm is inflicted on others, preventing the enforcement of the ownership right will be irrational and illegitimate, even if the dominance is irrational. However, certain irrational dominations are counted illegal (Makarem Shirazi, 1961, v1, p19).

Two issues: prohibition of change of use and the prohibition of less than quorum segmentation regarding agricultural and garden lands are two different issues used to enforce one policy, which is retention of agricultural lands.

The most important negative effect of segmenting the lands and making them smaller in size, is the irrational increase in the cost of production per unit of area. In Iran, 84\% of the exploiters of agriculture have only 4.2 hectares of land. Because of this, farmers are oriented towards using manpower since using machinery will not be profitable, and so the agricultural lands will be subjected to non-agricultural uses. In this sense, farmers must not only think about their production, but also should think about providing for their families, and this is followed by several harmful consequences for Iran's agriculture sector. Nowadays, many countries are envisaging strict rules to prohibit land use change, and will seriously enforce such rules to preserve their farms, gardens, jungles, ranges, and other natural lands. To this end, they use deterrent and persuasive methods. In Iran, the main reason behind segmentation of lands is inheritance, in a way that annually roughly 200.000 hectares of agricultural lands are getting smaller due to insufficiency of laws, and consequently the mechanization of such lands becomes infeasible. In countries such as France, Germany and Sweden, the inheritance laws are laid in a way that after the passing of the owners (parents), the and will be given to the older children, especially male children, and by leaving the farming to one of the children, the entire benefits will be divided between the entire inheritors. However, considering the other belongings of the deceased, decisions are made in a way that the land is inherited to one or two individuals, while other properties are inherited by others. In this sense, similar to factories, cars and other belongings, lands too will not be segmented. In addition to the mentioned issues, another issue Iran is suffering from is lack of expert and professional care at the time preparing laws and regulations. Issuing regulations as amendments to previous laws resulted in increase in the number of exploiters of the agriculture sector, which shows that the agricultural lands are getting smaller and smaller. Also the proposed solutions such as forming agricultural public held corporations and forming public groups have not been effective, in fact no decisive action has been administered to integrate the issue and avoid the segmentation of agriculture lands. Undoubtedly, the heavy consequences of such decisions will not be repaired anytime soon.

\section{Challenges}

1- Overwhelming increase in the area of cities and expansion to the agricultural and garden lands in a way that many cities have urban areas much larger than the region's population requirement. In addition, the outskirts of towns and cities are very large, in some cases even up to 50 times larger than the area of the city or town itself.

2- Transforming villages with populations above 3500 to cities, and turning a generator society into a consumer one.

3- Lack of abiding of laws by corporations and organizations backed by state departments, in constructing structures, and taking permits from the ministry of agriculture to change the use of agricultural and garden lands.

4- Extensive advertising in radio, television, media, papers, urban areas and by telephone 
operators regarding construction of residential and recreational structures in agriculturally potent areas.

5- Lack of land management plans, and plans for anticipation of public requirements (lack of proper tourism and public residential centers).

6- Unauthorized granting of construction permits by certain state departments including the governors' offices. In fact, certain people at such organs believe granting such illegal permits is a source of income. In addition, they also do so by granting permits for construction on agricultural lands, and by granting running water, gas and electricity utility permits, which will be considered as legal state permits by courts, and resultantly the offenders will be exonerated.

7- Establishment of industrial parks on agricultural lands.

Based on the content of the article 1 of the law of retention of use of agricultural and garden lands, we have: the reason why this law has been envisaged, is to sustain such lands' efficiency. However, forming a commission for change of use shows that in certain cases, issuing a permit for changing the use of land with the intention of developing other sectors such as housing and urban planning, industry and etc. is inevitable. According to the objectives listed in the article 1 and other laws such as the constitution, it seems that the following solutions must be used to promote a balanced development of agriculture and industry:

1- Executing plans of cadaster of agricultural lands throughout the country.

2- Preventing the formation of suburban living places, and preventing the development of towns and cities towards agricultural lands and lands potent for agriculture (national and state lands). Making use of non-agricultural lands for construction of residences, new cities, industrial plants, workshops, and generally, for making physical changes that would alter the use of agricultural lands.

3- Amending the laws relating to reducing city skirts, which have irrationally increased in the past years.

4- Establishing coordination between public and state organs such as municipalities, governors' offices, registration offices, gas, electricity and water companies, and other related offices, and the ministry of agriculture will play an important and effective role in prevention of unauthorized change of land use. Taking a permit from the agriculture ministry prior to changing the use of a land, will reduce the number of cases of unauthorized land use change.

5- Proper execution of the national regulations regarding land management, issued in 2005 by the board of ministers, especially for agriculture and industry sections, will help with reaching the goals of the law of retention of use of lands.

\section{Discussion}

According to jurisprudential bases, the principle of dominance, and the article 30 of the civil code, owners are allowed to dominate their owned properties in any materialistic or nonmaterialistic manner. The range of dominations exercisable by owners varies depending on the type and manner of domination. In some cases, the dominations may cause harms and damages to the neighbors. In such cases, the principle of no-harm takes over the dominance principle and prevents the occurrence of probable damages. This in turn limits the ownership rights of owners; however, such cases are not the only causes of limiting ownership rights. Rather, with respect to the ever increasing population which has caused accelerated growth in urbanism, migration of rural work forces to the cities, establishment of industrial units in the outskirts of cities, daily increase in the number and expansion of towns and complexes, streets, roads, landscapes, public spaces, health-care and medical sites, public-service sites, dominating and owning the properties of owners by law enforcement organizations is becoming more and more 
evident as a social necessity. Therefore, state organizations such as municipalities, sometimes misuse their legal authorities with respect to owning, and laying regulations targeting the trades of properties; and therefore violate ownership rights.

\section{Conclusions}

Results of the present study have shown that according to the principle of dominance, ownership right is absolute and real for the owners of rights. But in cases where these personal rights come into conflict with public rights, based on reason and ration, the public rights must be preferred, and the personal rights must be limited and controlled. This preference has a clear and obvious instance in the context of changing the use of agricultural and garden lands; and it is rational that the society's right will be dominant over the rights of the owner of agricultural and garden lands. Efficiently enforcing the law of retention of use of lands, requires coordination between the ministry of agriculture and other public organs such as the legal and state authorities. Agricultural lands are in fact national assets to create which, large amounts of energy and time are spent. Undoubtedly, to satisfy their basic life requirements, humans depend on earth (land). With respect to Iran's current climate, leaving the country with only a limited amount of potent agricultural lands, non-scientific and wrong interventions are resulting in reduction of production rate per hectare. Currently, the irrational change of use of agricultural lands is considered as one of the most important challenges of Iran's agriculture. Changing the use of lands, excludes many agricultural lands from the chain of production every year. The most important reasons for tendency towards changing the use of lands include: lack of development of agriculture, the fact that Iran's agriculture is not economic, lack of information and improper execution of construction plans, urban development plans, and tendency of the youngsters towards occupations other than farming. On the other hand, through improving the interestingness of farming for farmers, precise execution of rural development plans with emphasis on retention of land use, and mitigating the negative repellants of living in villages, and managing construction on agricultural lands can prevent the society's, especially the farmers' tendency towards changing the use of agricultural lands.

\section{References}

Ansari, S. M. (1997). Al-Makasib, fourth edition, Dar al-Hikma, Qom.

Emami, S. H. (2004). Civil Law, Vol. 1, 24th Edition, Tehran, Islamic Bookstore Publications.

Ghahremani, N. (2005). A comparative study of how to resolve the conflict between the principle of domination and the no-harm rule. Journal of the Bar Association, 5. 188189.

Ibn Abd Rabba, Abu Umar Ahmad ibn M. (1940). Al-Aqd Al-Farid, vol. 2, Cairo.

Ibn Qadameh. (1983). Al-Mughni, vol. 5, Beirut: offset printing.

Katozian, N. (2009). Property, 26th edition. Tehran, Justice Publications.

Mahmoudi Golpayegani, M. (2005). Legal Study of hoarding and its rating. Journal of the Faculty of Law and Political Science, 68, 90-115.

Makarem Shirazi, N. (1993). Anwar al-Faqih, vol. 5, second edition, Qom: Imam Amir alMo'menin School.

Makarem Shirazi, N. (1980). Rules of Jurisprudence, vol. 1, first edition, Qom, Dar al-Alam.

Mohaghegh Damad, S. M. (2002). Rules of Jurisprudence(Civil Department ); Vol. 2, Ch. 5, Tehran: Organization for the Study 
and Compilation of Humanities Books, Samat

Mohaghegh Sabzevari, M. Baqir Ibn M. (1969). Kefayat al-Ahkam, Qom: offset printing.

Mustafavi, M. K. (1996). Rules: The essence of the rule of jurisprudence, meaning, evidence and case, Qom: Bina.

Najafi, H. (2015). Jawahar al-Kalam; Volume 29, Ch 6, Tehran: Islamic Library.

Nosrati Sedghiani, N. (2010). Abuse of Property Rights in Apartments, Payame Noor University of Tehran, Master Thesis in Private Law.

Sheikh Tusi, M. Ibn H. (1932). Al-Mabsut Fi Fiqh Al-Ummahiyyah, vol.

Sistani, A. (1993). The rule of no harm and no harm, Beirut.

Tavakoli, S. (2002). The rule of dominance and the rule of no harm in the Iranian legal system. Judicial Monthly, 35, 176-188. 